\title{
NOTE
}

\section{Virus-associated papillomatous skin lesions in a giant guitarfish Rhynchobatus djiddensis: a case report}

\author{
Alvin Camus ${ }^{1, *}$, Jennifer Dill ${ }^{1}$, Alexa McDermott ${ }^{2}$, Melinda Camus ${ }^{1}$, \\ Terry Fei Fan $\mathrm{Ng}^{1,3}$
}

\begin{abstract}
${ }^{1}$ Department of Pathology, College of Veterinary Medicine, University of Georgia, Athens, Georgia 30602, USA
${ }^{2}$ Department of Veterinary Services, Georgia Aquarium, Inc., 225 Baker Street NW, Atlanta, Georgia 30313, USA

${ }^{3}$ Present address: Division of Viral Diseases, National Center for Immunization and Respiratory Diseases, Centers for Disease Control and Prevention, Atlanta, Georgia 30329, USA
\end{abstract}

\begin{abstract}
Although elasmobranch species are increasingly displayed in public aquaria, knowledge of disease in wild and captive elasmobranchs, as well as the agents involved, remains limited, and descriptions are often incomplete. This report describes papillomatous skin lesions in a juvenile giant guitarfish Rhynchobatus djiddensis associated with intranuclear viral particles. Skin biopsies were collected from multiple, friable, raised, villonodular skin lesions affecting pigmented and non-pigmented skin of the caudal fin and ventrum, respectively. Microscopic examination revealed papillary proliferation of the epidermis, with widespread marked karyomegaly of squamous epithelial cells. In approximately $75 \%$ of nuclei, chromatin was marginated by one to multiple, large, amphophilic inclusions. Large numbers of unencapsulated, $75 \mathrm{~nm}$, icosahedral viral particles were observed to form large arrays in affected nuclei using transmission electron microscopy. Based on intranuclear location, particle size and morphology, a consensus nestedPCR for adenovirus polymerase was attempted. However, no adenoviral gene sequence was amplified. The nature of the involved virus remains unknown and an ongoing area of investigation. Lesions regressed completely over a 6 mo period, during which time the animal showed no signs of systemic illness, and there has been no recrudescence for 6 mo following resolution. Two cohorts of similar age and in close contact with the case animal were unaffected.
\end{abstract}

KEY WORDS: Virus · Skin lesion · Histopathology $\cdot$ Giant guitarfish

\section{INTRODUCTION}

Examples of viral disease are extremely limited in elasmobranchs (McAllister \& Stoskopf 1993, Terrell 2004). While viral particles have been observed in skin and gill lesions, none have been isolated in culture or characterized molecularly (Leibovitz \& Lebouitz 1985, Bowman et al. 2008, Garner 2013). In a 16 yr retrospective study of 1546 captive elasmo- branch cases, $15(1 \%)$ were attributed to viral disease, including 2 cases of herpesvirus dermatitis and 6 cases of adenovirus dermatitis and branchitis. Presumptive viral papillomatosis, with no observation of inclusion bodies or viral particles, was diagnosed in an additional 7 cases in which spontaneous regression of lesions often occurred (Garner 2013).

Epizootic dermatitis in wild-caught and laboratorymaintained smooth dogfish Mustelus canis has been 
associated with herpesvirus-like particles visualized budding from nuclear and cytoplasmic membranes. Small, circular, depigmented plaques increased to over $1 \mathrm{~cm}$ in diameter and developed dark depressed centers surrounded by whitish-gray zones and outer raised granular reddened margins. Histologically, intracellular edema and degeneration of the basal epithelium was accompanied by eosinophilic cytoplasmic inclusions and intranuclear inclusions surrounded by halos. Central epidermal necrosis was bordered by vesicle formation, peripheral ballooning degeneration and hemorrhage. Lesions were most numerous on the tail and fins, often coalesced and resolved spontaneously with melanization. There were no signs of systemic illness, and infection was postulated to be stress related (Leibovitz \& Lebouitz 1985). Garner (2013) reported virtually identical lesions in both the smooth and spiny dogfish Squalus acanthias.

Adenovirus-associated inclusion body branchitis and dermatitis has also been described in a group of wild-caught juvenile smooth dogfish undergoing quarantine. Anorexia, ulcerative dermatitis and ultimately $100 \%$ mortality were observed clinically. Microscopic lesions attributable to viral infection were not seen in all animals but when present included hypertrophy and hyperplasia of the oral mucosal epithelium and marked branchitis. Both oral and branchial epithelial cells had large intranuclear inclusions containing hexagonal 60-65 nm viral particles, most suggestive of an adenovirus (Bowman et al. 2008, Garner 2013).

Although descriptions are not well documented and host records confused, small intracytoplasmic inclusions, attributed to viral erythrocytic necrosis (VEN), have been reported in stained blood smears of erythrocytes from the small-spotted catshark Scyliorhinus canicula (Johnston 1975) and the little skate Raja erinacea (Khan \& Newman 1982). McAllister \& Stoskopf (1993) describe sharks with low hematocrits, pale gills and organs, and hyperplastic hematopoietic tissues. Molecular evidence from teleosts supports inclusion of the VEN virus within the family Iridoviridae (Emmenegger et al. 2014).

Compared to teleost fish, relatively few specific disease entities or agents are recognized among the Chondrichthyes (Terrell 2004). This report describes gross, histopathologic and transmission electron microscopic (TEM) findings from a case of viral-associated papillomatous skin disease in a giant guitarfish Rhynchobatus djiddensis. A rajiform member of the superorder Batoidea, the skates and rays, giant guitarfish are displayed in public aquaria and are also taken commercially and for sport. Their status is listed by the IUCN as Vulnerable. Native to the Red Sea and western Indian Ocean, adults reach lengths of $3.1 \mathrm{~m}$ and weights of $227 \mathrm{~kg}$ (Froese \& Pauly 2014).

\section{MATERIALS AND METHODS}

\section{Fish and case history}

A $148 \mathrm{~cm}, 13.5 \mathrm{~kg}$, juvenile, male giant guitarfish Rhynchobatus djiddensis, was one of 3 animals that arrived in good body condition, following international shipment to the Georgia Aquarium, Atlanta, GA, USA, in July 2014. Consistent with capture and transport, physical examination revealed multiple superficial abrasions and erythema around the mouth, as well as ventral aspects of the body wall, pectoral, pelvic and caudal fins. Skin scrapes were negative for external parasites. The fish received an intramuscular (i.m.) injection of $6.6 \mathrm{mg} \mathrm{kg}^{-1}$ ceftiofur crystalline (Excede, Zoetis) and $0.065 \mathrm{mg} \mathrm{kg}^{-1}$ i.m. vit E/Se (Schering-Plough Animal Healthx). Erythematous areas had improved after $1 \mathrm{wk}$ and a second Excede injection was administered. Additional treatments included two $48 \mathrm{~h}$ immersions in a $6 \mathrm{mg} \mathrm{l}^{-1}$ solution of praziquantel (Medisca).

Over the next $7 \mathrm{wk}$, the fish ate well and behaved normally, although minor ventral erythema persisted. The following week, reddened skin sites changed rapidly in appearance. Affected areas began to enlarge and became raised and increasingly erythematous. A black pigmented lesion was also noted on the right ventral lobe of the caudal fin. A second series of skin scrapes were negative for parasites, but cytology revealed large numbers of cocci and small numbers of leukocytes. A regimen of $22 \mathrm{mg} \mathrm{kg}^{-1}$ i.m. ceftazidime (Tazicef, Hospirax) once every $4 \mathrm{~d}$ (total of 5 injections) and $12.5 \mathrm{mg} \mathrm{kg}^{-1}$ vitamin C per os once daily for $14 \mathrm{~d}$ (Vet One, MWI Veterinary Supply) was initiated. Skin biopsies were collected 1 wk later.

\section{Biopsy, histopathology and cytology}

Biopsy specimens were collected using manual restraint while the fish remained in its tank. Two ventral lesions and an area of the right caudal fin lesion were blocked with $0.5 \mathrm{ml}$ of lidocaine (Hospira) each, and $4 \mathrm{~mm}$ punch biopsies were collected. Biopsy sites were treated for $5 \mathrm{~d}$ with tricide/baytril (Tricide, Molecular Therapeutics, LLC; Baytril, Bayer Animal 
Health, respectively). Tissue samples were fixed in $10 \%$ neutral buffered formalin, processed routinely, embedded in paraffin, sectioned at $5 \mu \mathrm{m}$, and stained with hematoxylin and eosin (H\&E) and Fuelgen stain (Allen 1992, Carson 1997). Following initial histopathologic evaluation, additional biopsy specimens were collected the following week using similar methods for cytologic evaluation and electron microscopy. Impression smears of biopsy material were stained using a modified Wright's stain.

\section{TEM and PCR}

Approximately $2 \mathrm{~mm}$ cubes of skin were fixed overnight in a solution of $2 \%$ glutaraldehyde, $2 \%$ paraformaldehyde and $0.2 \%$ picric acid in $0.1 \mathrm{M}$ cacodylate-HCl buffer $(\mathrm{pH}$ 7.0-7.3). Tissues were then post-fixed in $1 \% \mathrm{OsO}_{4}$ for $1 \mathrm{~h}$, dehydrated in a series of ethanols, stained 'en bloc' with $0.5 \%$ uranyl acetate and embedded in Epon-Araldite (Electron Microscopy Sciences). Ultrathin sections were cut on a Reichert Ultracut S ultramicrotome (Leica), stained with lead citrate and examined on a JEM-1011 TEM (JEOL USA).

A consensus nested-PCR method to amplify the polymerase gene of divergent adenoviruses was attempted following the procedure described by Wellehan et al. (2004).

\section{RESULTS}

\section{Gross, cytologic and histopathologic findings}

Well-demarcated, irregular, variably sized, fleshy, pale pink lesions were widely distributed over non-pigmented areas of the ventral body surface, involving the perioral area, claspers, pectoral and pelvic fins, and the fin bases. The friable, villonodular lesions were raised $1-3 \mathrm{~mm}$ above the skin surface (Fig. 1A). A single, roughly triangular, $12 \times 14 \times 14 \mathrm{~cm}$, black pigmented lesion was present on the mid-ventral aspect of the right caudal fin and dorsolateral peduncle. The large caudal fin lesion had a slightly firmer, more nodular surface than the ventral lesion and a slightly depressed border (Fig. 1B).
Impression smears of biopsied tissue contained cohesive clusters of epithelial cells characterized by large round to ovoid nuclei, with coarsely granular chromatin and scant to small amounts of basophilic cytoplasm. Anisocytosis was difficult to assess, due to the absence of distinct cell borders, but anisokaryosis was moderate to marked. Multiple large nuclei contained a single, 10-20 $\mu \mathrm{m}$ in diameter, round, bright magenta inclusion body. Free inclusions and fine black pigment granules were scattered throughout the background (Fig. 2A).

Microscopic examination of biopsy specimens revealed broad villus-like proliferations of the epidermis supported by a scant fibrovascular stroma (Fig. 2B). Basal cells were unaffected, forming a single, uninterrupted, cuboidal to low-columnar layer upon a thick contiguous basement membrane (Fig. 2C). The remaining hyperplastic epithelial cells were dominated by marked cytokaryomegaly. Approximately $75 \%$ of nuclei contained one to several, amphophilic inclusions with a variable ground glass to hyaline appearance. A single, large, Fuelgen-positive inclusion often filled and expanded the entire nucleus, resulting in severe margination of chromatin. Less frequently, nuclei contained multiple inclusions and variably sized clear spaces. Additional nuclei, primarily within central areas of papillae, were also enlarged but contained degenerateappearing, pale-staining, condensed, fragmented debris accompanied by large areas of clear space.

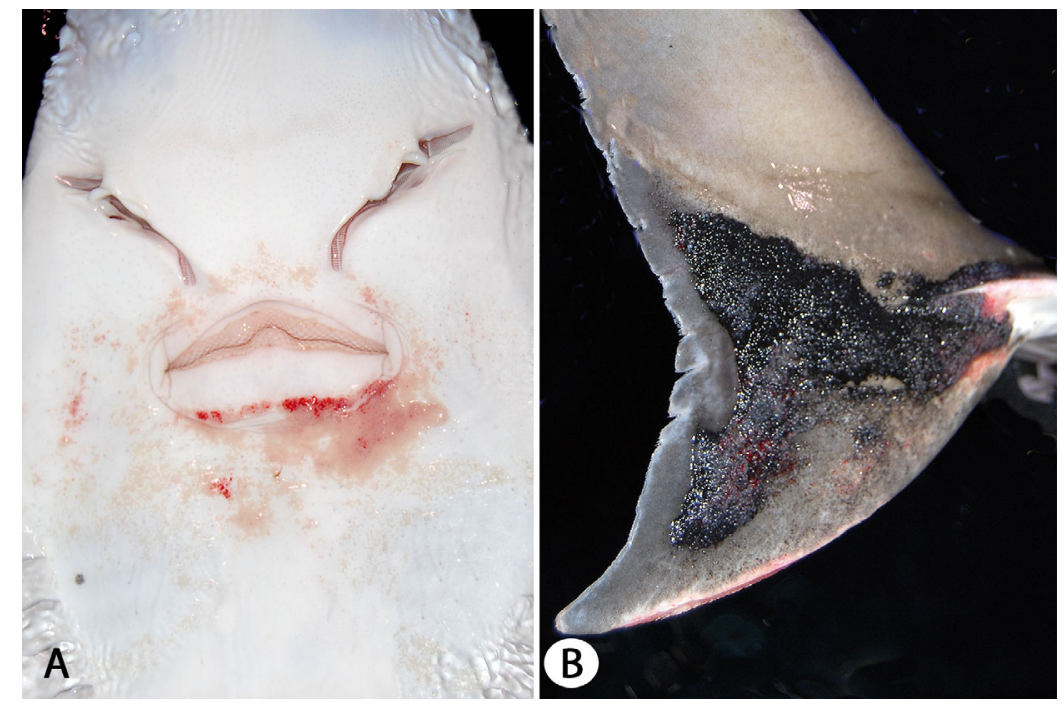

Fig. 1. Rhynchobatus djiddensis. Gross photographs of proliferative, viralassociated skin changes in a giant guitarfish. (A) Non-pigmented, perioral skin with slightly raised, pale pink, villonodular skin lesions that were easily traumatized and often erythematous. (B) Pigmented skin of the right aspect of the caudal fin and peduncle, with a large $12 \times 14 \times 14 \mathrm{~cm}$, raised, heavily melanized, finely nodular, skin lesion 


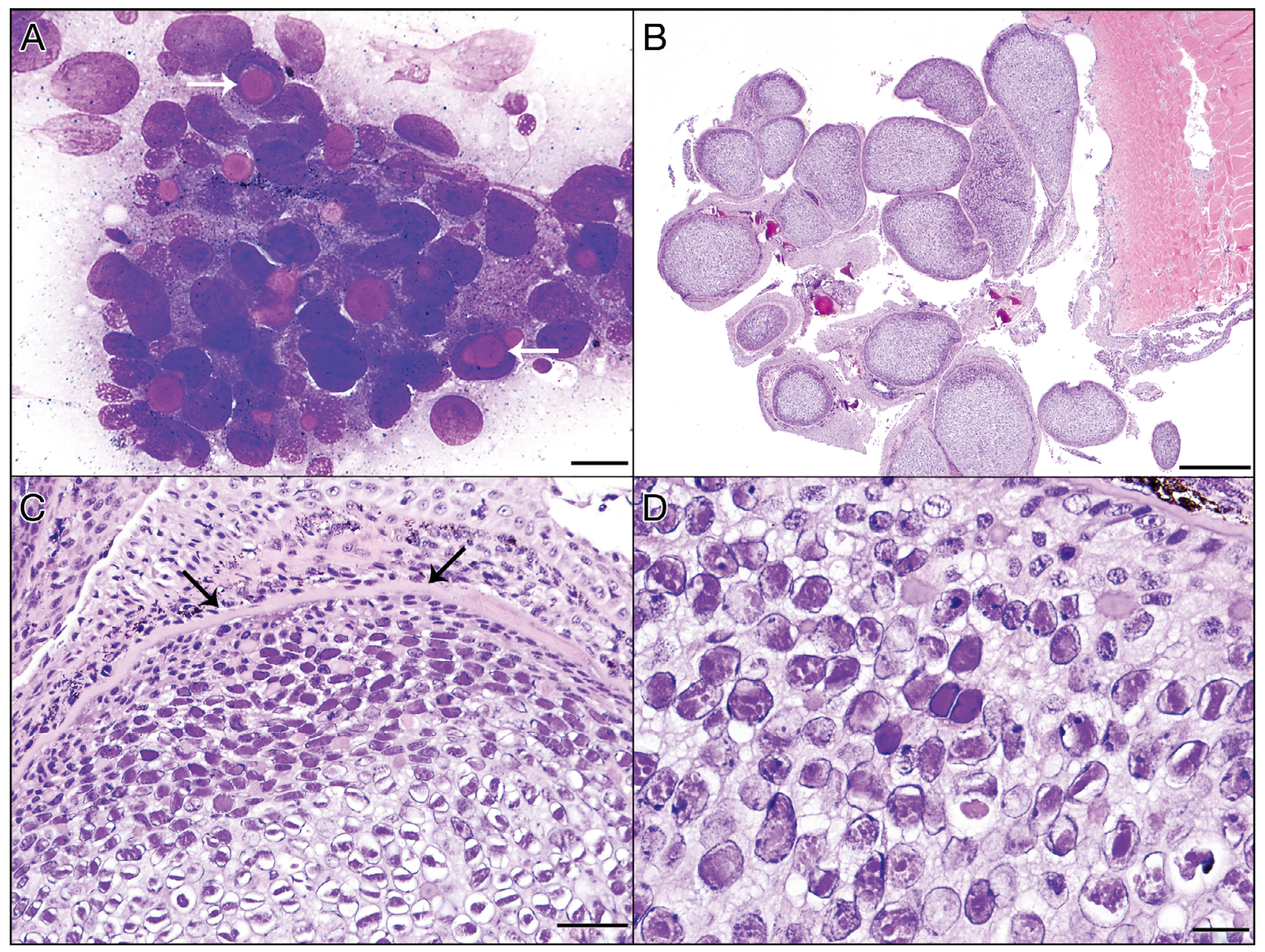

Fig. 2. Rhynchobatus djiddensis. Photomicrographs of viral-associated skin lesions in a giant guitarfish. (A) Wright's stained cytologic impression of an epithelial cell cluster. Multiple nuclei are enlarged by round, magenta inclusions (white arrows). Free inclusions are scattered throughout. Scale bar $=20 \mu \mathrm{m}$. (B) Low magnification image demonstrating papillary proliferation of the epidermis (H\&E). Scale bar $=500 \mu \mathrm{m}$. (C) Area of epithelial cell proliferation. Basement membranes were continuous, thick (arrows) and lined by unaffected basal cells. Amphophilic inclusions enlarge the nuclei of virtually all remaining cells. Scale bar $=50 \mu \mathrm{m}$. (D) Higher magnification of nuclei with marginated chromatin and viral inclusions that varied from single and hyaline to pale and fragmented, with surrounding clear space (H\&E). Scale bar $=20 \mu \mathrm{m}$

Pale eosinophilic cytoplasm was finely granular in the basilar epithelial layers but became increasingly flocculent to vesicular in cells with nuclear inclusions. There was no evidence of inflammatory infiltrates or vascular changes in the sections examined.

\section{TEM and PCR}

Epithelial cell nuclei contained variably sized arrays of viral particles that marginated chromatin against the nuclear membrane (Fig. 3A). The icosahedral particles were $75.08 \pm 3.56 \mathrm{~nm}(\mathrm{n}=20)$ along their greatest dimension and some had a vaguely discernable, dense, round, central core (Fig. 3B). Virus particles were limited to the nucleus, with no evidence of membrane budding.

An adenoviral DNA polymerase gene consensus nested-PCR failed to amplify a specific product.

\section{DISCUSSION}

Reports of viral-induced disease in elasmobranchs are rare (McAllister \& Stoskopf 1993, Terrell 2004, Garner 2013). While viral particles with morphologic features of herpes and adenoviruses have been observed by electron microscopy in cases of dermatitis in dogfish, none have been cultured or characterized molecularly (Leibovitz \& Lebouitz 1985, Garner 


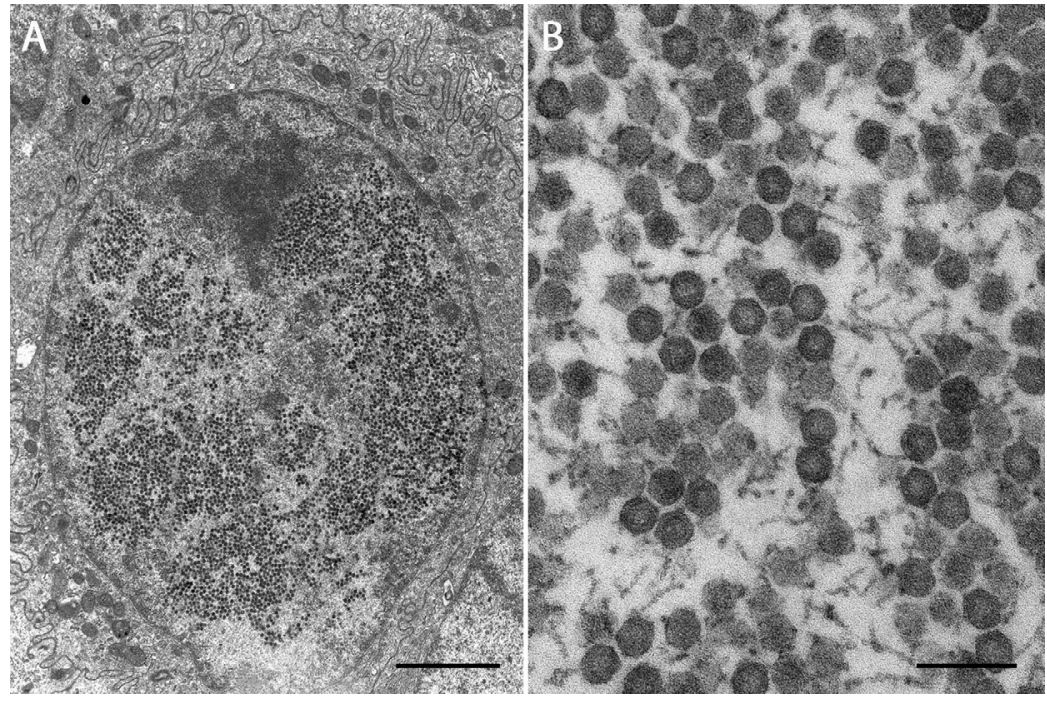

Fig. 3. Rhynchobatus djiddensis. Electron micrographs of viral-associated skin lesions from a giant guitarfish. (A) Epithelial cell nucleus containing multiple arrays of viral particles that marginated the nuclear chromatin. Scale bar $=$ $2 \mu \mathrm{m}$. (B) Higher magnification image of individual icosahedral viral particles with an average size of $75 \mathrm{~nm}$. A central round core can be visualized in some particles. Scale bar $=200 \mu \mathrm{m}$

2013). Viral etiologies have been suspected in cases of papillomatosis in several elasmobranch species, although inclusion bodies and viral particles were not observed (Garner 2013). The Present report describes a previously unknown virus-associated papillomatous skin disease in a giant guitarfish. Microscopic lesions were characterized by widespread karyomegaly in Malpighian cells, accompanied by large numbers of Fuelgen-positive intranuclear inclusions, consistent with a DNA virus. The hexagonal particles formed large arrays and fell within the 70-90 nm size range of adenoviruses (King et al. 2012).

Gross and microscopic lesions in this case differed significantly from herpesvirus dermatitis in the smooth dogfish (Leibovitz \& Lebouitz 1985). Lesions in the guitarfish were papillary rather than plaquelike, basal cells were unaffected, vesicle formation was not observed, and numerous amphophilic inclusions filled and distended nuclei. In the dogfish, inclusions were smaller, eosinophilic, both nuclear and cytoplasmic, and nuclear inclusions were often surrounded by a halo. Viral particles in the guitarfish were limited to epithelial cell nuclei. Particles in dogfish were present in nuclei, cisternae of the endoplasmic reticulum and in intercellular spaces. Virions possessed a dense core, bilayered envelope and ranged from 150 to $185 \mathrm{~nm}$ in diameter.

In contrast, lesions and virus morphology share similarities with features of adenoviral and adeno- virus-like diseases of the smooth dogfish and several teleosts (Jensen \& Bloch 1980, Hedrick et al. 1985, Bloch et al. 1986, Miyazaki et al. 2000). Inclusion body branchitis and dermatitis in dogfish affects both lamellar and oral epithelial cells. Lamellar and hyperplastic oral epithelial cells contain large intranuclear inclusions with arrays of hexagonal virus particles. Grossly, only skin was involved in this guitarfish, and the $75 \mathrm{~nm}$ particles were larger than the $60-65 \mathrm{~nm}$ viral particles reported in dogfish (Bowman et al. 2008, Garner 2013).

In teleosts, nuclear inclusions with non-enveloped adenovirus and adenovirus-like particles have been associated with a number of conditions affecting epithelial surfaces. Chronic mortality in juvenile white sturgeon Acipenser transmontanus is caused by an ichtadenovirus. Enterocytes have markedly enlarged nuclei distended by inclusions with $74 \mathrm{~nm}$ viral particles (Hedrick et al. 1985, Kovács et al. 2003, King et al. 2012). Hyperplastic epidermal plaques in cod Gadus morhua and dab Limanda limanda have nuclear inclusions with 77 and $80 \mathrm{~nm}$ particles, respectively, in superficial layers of the epithelium (Jensen \& Bloch 1980, Bloch et al. 1986). More recently, $78-83 \mathrm{~nm}$ adenovirus-like particles have been observed in the enlarged nuclei of lymphoblastoid cells of leukemic red sea bream Pagrus major (Miyazaki et al. 2000).

Interestingly, the $75 \mathrm{~nm}$ particles in the guitarfish lesion are identical in size and morphologically similar to an unclassified DNA virus isolated from Japanese eels Anguilla japonica affected by viral endothelial cell necrosis of eel (VECNE). The primary lesion of VECNE is vascular necrosis, affecting multiple organs, including gill lamellae. Hypertrophied endothelial cells, as well as the lamellar epithelium and pillar cells, have large nuclear inclusions containing virus particles (Ono \& Nagai 1997, Mizutani et al. 2011). VECNE produces high mortalities in eels, while lesions in this guitarfish regressed spontaneously, without clinical evidence of systemic disease.

This report describes a case of proliferative skin disease in a giant guitarfish. Lesions developed from areas of erythematous skin were thought to be related to trauma incurred during transport. Lesions persisted for over 6 mo but began to resolve sponta- 
neously after approximately $4.5 \mathrm{mo}$. In the interim, microscopic examination of affected skin revealed large numbers of epithelial cells with intranuclear inclusions containing arrays of unidentified $75 \mathrm{~nm}$ virions. There has been no recurrence of lesions for 6 mo post-resolution, and the 2 guitarfish acquired with the case animal have remained asymptomatic. Particle size, lack of an envelope and localization to the nucleus are suggestive of an adenovirus, although a polymerase-targeted consensus PCR was negative. However, adenoviral polymerase sequences in fish may differ significantly from those of other Adenoviridae, and the possibility of an unidentified or unclassified virus cannot be ruled out (Benkö et al. 2002). Cell culture was not attempted in this case due to a lack of appropriate cell lines. Characterization of the rare viral agents associated with disease in elasmobranchs is limited to electron microscopic descriptions of virion size and morphology. Characterization of the virus observed in this case remains an area of active investigation, including next generation sequencing.

Acknowledgements. The authors thank Mary Ard at the College of Veterinary Medicine, University of Georgia, for her assistance with the processing of samples for electron microscopy.

\section{LITERATURE CITED}

Allen TC (1992). Hematoxylin and eosin. In: Prophet EB, Mills B, Arrington JB, Sobin LH (eds) Armed Forces Institute of Pathology laboratory methods in histotechnology. American Registry of Pathology, Washington, DC, p 53-58

Benkö M, Élö P, Ursu K, Ahne W, LaPatra S, Thomson D, Harrach B (2002) First molecular evidence for the existence of distinct fish and snake adenoviruses. J Virol 76: 10056-10059

Bloch B, Mellergaard S, Nielsen E (1986) Adenovirus-like particles associated with epithelial hyperplasias in dab, Limanda limanda (L.). J Fish Dis 9:281-285

Bowman M, Ramer J, Proudfoot J, Stringer E, Garner M, Trupkiewicz J, Giray C (2008) A novel adenovirus in a collection of wild-caught dusky smooth-hounds (Mustelus canis). In: 2008 Proceedings AAZV ARAV Joint Conference, Los Angeles, CA. American Association of Zoo Veterinarians, Yulee, FL, p 208-209

Carson FL (1997) Histotechnology: a self-instructional text, 2nd edn. American Society of Clinical Pathology Press, Chicago, IL, p 102-103

Editorial responsibility: V. Gregory Chinchar, Jackson, Mississippi, USA
Emmenegger EJ, Glenn JA, Winton JR, Batts WN, Gregg JL, Hershberger PK (2014) Molecular identification of erythrocytic necrosis virus (ENV) from the blood of Pacific herring (Clupea pallasii). Vet Microbiol 174:16-26

Froese F, Pauly D (2014) FishBase. www.fishbase.org (accessed 28 Jan 2015)

Garner MM (2013) A retrospective study of disease in elasmobranchs. Vet Pathol 50:377-389

> Hedrick RP, Speas J, Kent ML, McDowell T (1985) Adenovirus-like particles associated with a disease of cultured white sturgeon, Acipenser transmontanus. Can J Fish Aquat Sci 42:1321-1325

Jensen NJ, Bloch B (1980) Adenovirus-like particles associated with epidermal hyperplasia in cod (Gadus morhua). Nord Vet Med 32:173-175

Johnston MR (1975) Distribution of Pirhemocyton Chatton \& Blanc and other, possibly related, infections of poikilotherms. J Protozool 22:529-535

Khan RA, Newman MW (1982) Blood parasites from fish of the Gulf of Maine to Cape Hatteras, Northwest Atlantic Ocean, with notes on the distribution of fish hematozoa. Can J Zool 60:396-402

King AMQ, Adams MJ, Carstens EB, Lefkowitz EJ (2012) Family Adenoviridae. Virus taxonomy, classification and nomenclature of viruses. Ninth Report of the International Committee on Taxonomy of Viruses. Elsevier, Academic Press, London, p 125-141

> Kovács GM, LaPatra SE, D'Halluin JC, Benk M (2003) Phylogenetic analysis of the hexon and protease genes of a fish adenovirus isolated from white sturgeon (Acipenser transmontanus) supports the proposal for a new adenovirus genus. Virus Res 98:27-34

> Leibovitz L, Lebouitz SS (1985) A viral dermatitis of the smooth dogfish, Mustelus canis (Mitchell). J Fish Dis 8: 273-279

McAllister PE, Stoskopf MK (1993) Shark viruses. In: Stoskopf MK (ed) Fish medicine. WB Saunders, Philadelphia, PA, p 780-782

Miyazaki T, Asai Y, Kobayashi T, Miyata M (2000) Lympholeukemia in madai Pagrus major in Japan. Dis Aquat Org 40:147-155

Mizutani T, Sayama Y, Nakanishi A, Ochiai H and others (2011) Novel DNA virus isolated from samples showing endothelial cell necrosis in the Japanese eel, Anguilla japonica. Virology 412:179-187

Ono S, Nagai A (1997) Electron microscopic observation and experimental infection of congestion in gills of Japanese eel, Anguilla japonica. J School Mar Sci Technol 43: 95-105

Terrell SP (2004) An introduction to viral, bacterial, and fungal diseases of elasmobranchs. In: Smith M, Warmolts D, Thoney D, Heuter R (eds) Elasmobranch husbandry manual: captive care of sharks, rays, and their relatives. Ohio Biological Survey, Columbus, OH, p 427-431

- Wellehan JF, Johnson AJ, Harrach B, Benko M and others (2004) Detection and analysis of six lizard adenoviruses by consensus primer PCR provides further evidence of a reptilian origin for the atadenoviruses. J Virol 78:13366-13369

Submitted: September 10, 2015; Accepted: November 25, 2015 Proofs received from author(s): January 6, 2016 